Radioprotection, vol. 44, $\mathrm{n}^{\circ} 5$ (2009) 463-468

(C) EDP Sciences, 2009

DOI: $10.1051 /$ radiopro/20095086

\title{
The EXTREME project consequences of paroxystic meteo climatic events on the translocation of contaminants within the geosphere
}

\author{
F. Eyrolle, O. Masson, C. Antonelli, M. Arnaud and S. Charmasson \\ Institute for radiological Protection and Nuclear Safety, Environment and Emergency \\ Operations Division, Environmental Radioactivity Study and Monitoring Department, \\ Continental and Marine Radioecological Research Laboratory, Centre de Cadarache, BP. 3, \\ 13115 Saint Paul-Lez-Durance, France \\ Associated partners: \\ CEFREM (CEntre de Formation et de recherche sur l'Environnement Marin) \\ Perpignan University, France \\ CEREGE (Centre Européen de Recherche et d'Enseignement des Géosciences \\ de l'Environnement), Aix-Marseille III University, France IFREMER, Brest and Toulon \\ Centres, France \\ Pôle d'Océanographie Côtière de l'Observatoire Midi-Pyrénées - Laboratoire d'Aérologie, \\ Toulouse University, France
}

\begin{abstract}
The EXTREME project was launched by the IRSN in 2005 to study the consequences of extreme meteo climatic events on reuptake of stocks and associated fluxes within the various compartments of the geosphere. Large masses of matter transferred during such events are liable to be displaced between locations, leading to higher pollution levels than those arising from average transfer processes, and producing pollutant fluxes that can be equivalent to the fluxes accumulated over several months or even years. This particularly concerns particle-reactive contaminants such as trace metals and long lived artificial radionuclides. The final aim of the project is to estimate the vulnerability of a coastal system (the Gulf of Lions, north western Mediterranean sea) to global change over the next 30 years. Indeed several programs dedicated to climate change predict a potential increase in the frequency of extreme events such as floods, floodings, saharian dust episodes, forest fire events and storms, particularly within the studied area.
\end{abstract}

\section{INTRODUCTION}

The environment is subject to natural and anthropogenic perturbations acting at highly variable time and space scales, and potentially leading to major imbalances or irreversible evolution. To understand such risks or hazards, it is necessary to take extreme phenomena into consideration and to detect instabilities. Several recent research programmes focused on exceptional phenomena (floods, swells, storms, winter vertical mixing, etc.) that strongly constrain mass budgets. This topic relates to the consequences of climate change, for which one of the main current observations is an amplification of seasonality and an increase in the occurrence of extreme meteo-climatic events. The latter can be manifold: 1- Strong precipitation for atmosphere-soil or soil-river transfers; atmospheric dust events of deposition of particles; 2- Floods for land-ocean fluxes or inside the land compartment in case of extreme flooding; 3- Floods, also, for transfer from the coastal environment to the deep sea; 4- Storms for sediment resuspension in coastal areas; 5- Cascading episodes of shelf waters into the deep sea environment. Such extreme events generate, over very short time periods, exceptional mass transfers and an intense redistribution of associated contaminants within the geosphere. Furthermore, these paroxystic events seem to play today a fundamental role both on contamination levels and distribution 
within the various compartments of the geosphere. Indeed, drastic decreases in primary pollutant inflow into the environment over the last decades, lead to amplify nowadays the contribution of secondary sources, accumulated in the past. Redistribution phenomena, whereby these accumulated inventories are remobilised, today play a major role, particularly during intense meteorological events. Large masses of matter are liable to be displaced between locations during such episodes, leading to higher pollution levels than those arising from average transfer processes, and producing pollutant fluxes that can be equivalent to the fluxes accumulated over several months or even years. This particularly concerns particle-reactive contaminants such as trace metals and long lived artificial radionuclides.

The EXTREME project was launched by the IRSN in 2005 to study the environmental impact of natural processes that generate exceptional fluxes or inventories in various environments: the atmosphere, soils, rivers, coastal areas and deep sea environments. The project is supported by the inter-regional program CARMA 2006-2008 and the ANR-EXTREMA project 2007-2010. EXTREME follows an integrated atmosphere/continent/sea approach in the coastal system of the Gulf of Lion. The choice of this experimental area was dictated by: 1- The vulnerability of this environment both to extreme episodes of meteo-climatic origin and to pollution sources, 2- Knowledge and existing expertise within the various compartments of this coastal system, 3- Available records and existing instrumented platforms on land and at sea. Based on these criteria, the distal part of the Rhône River and the catchment basin of the Têt River, their mouths and deltas, and the Gulf of Lion continental margin down to the deep (base of the slope), have been selected as the main working areas. EXTREME is targeted at two major contaminant families: artificial radionuclides $\left({ }^{137} \mathrm{Cs}\right.$ and transuranic nuclides) and trace metals (in particular $\mathrm{Pb}, \mathrm{Zn}, \mathrm{Cd}, \mathrm{Hg}$ and $\mathrm{Cu}$ ). The vulnerability of the environment to climatic hazards in the coming decades will be addressed by modelling mass transfers on the basis of different climate change scenarios.

\section{MATERIAL, METHODS AND EXPECTED RESULTS}

\subsection{The studied area}

The coastal environment of the Gulf of Lion is particularly interesting for studying the transfer of energy and materials from the land to the open ocean system. With an area of about $12000 \mathrm{~km}^{2}$, its shelf is one of the largest in the Mediterranean Sea. It is characterized by large amounts of terrestrial material inputs and high rates of biological productivity. It is also one of the few places in the Mediterranean where deepwater formation occurs. Sediment inputs to this environment are dominated by those from the Rhône River, which is now, after the damming of the Nile River, the most important river of the Mediterranean in terms of freshwater discharge (Ludwig et al., 2003). At least $80 \%$ of the riverine inputs of total suspended sediments into the Gulf of Lion come from this river (Durrieu de Madron et al., 2000). The remaining part is delivered by the small coastal rivers, mainly in the form of intermittent pulses triggered by flash floods. Atmospheric deposits of particulate matter mostly derive from crust-rich Saharan aerosols, but anthropogenic-rich European aerosols are also introduced into the study area (Avila et al., 1998; Caquineau et al., 1998; Blandin et al., 2002; Dulac et al., 2004; Pham et al., 2004).

\subsection{Monitoring and sampling through multi-instrumented platforms}

EXTREME relies, to a large extent, on several existing experimental platforms implemented by the partners in various compartments of the Gulf of Lion coastal system. Some are running for several years now, others are more recent. Specially adapted to extreme events, they are designed to monitor liquid and/or solid fluxes and associated pollutant. They automatically provide samples for chemical analysis at preset intervals, which is the only way to access sampling during harsh weather conditions. The OPERA platform run by IRSN dedicated to (1) sampling of both atmospheric wet and dry depositions, 
and (2) sampling of the Rhône River solid load. The POEM-LR2 observation and sampling platform has been installed by CEFREM in 2003-2004 on the coupled freshwater/saltwater system of the Têt River. The FRAME instrumentation, developed by IFREMER, is a small autonomous benthic station that becomes active on event detection. Additional sampling and instruments are necessary in some key compartments of the system. This especially concerns the bottom solid load transferred by the Rhône River. Riverbanks are known to be important reservoirs for the temporary storage of riverine pollutants (Maillet, 2006; Rolland, 2006). These sites will serve as sediment archives to reconstruct the recent history of heavy metal concentrations in the Rhône and Têt sediments. At the Rhône mouth, data acquisition also relies on instrumentation deployed by the CARMA project: Continuous measurements of currents, frequency/direction of waves, temperature, pressure, salinity, turbidity are performed. The transfer of suspended particles and associated elements from the coastal waters to the open marine system mainly passes through the submarine canyons into the Gulf of Lion shelf. Periods of cold dense water cascading play a crucial role in this transport. Several canyons have been equipped with sediment traps and current meters during previous research projects by the EXTREMA partners.

\subsection{The selected contaminants}

EXTREME focus on five trace elements $(\mathrm{Pb}, \mathrm{Zn}, \mathrm{Cd}, \mathrm{Cu}$ and $\mathrm{Hg}$ ) that have been recognized major anthropogenic origin and a serious environmental impact and toxicity on ecosystems. There has been a significant reduction in anthropogenic radioactivity inflows and fallout over the last decades. The last atmospheric nuclear weapons tests took place in 1980, and the Chernobyl accident was in 1986. Likewise, for most radionuclides, there has been a significant reduction in activity released from nuclear facilities, under statutory monitoring, over the last 15 years, due to changing activities, technical improvements and the implementation of strict directives regarding environmental protection (Charmasson et al., 1998; Charmasson et al., 2003; Eyrolle et al., 2004a, b). Although artificial radionuclides such as ${ }^{137} \mathrm{Cs}$ and transuranic nuclides are observed at ultratrace levels $\left(10^{-15} \mathrm{ppm}\right)$ within the present day environment, they represent a historical concern with respect to human health protection. These pollutants are particularly involved by the reworking of sedimentary reservoirs mainly since primary sources from nuclear industries declined and represent fundamental tools in assessing sediment dynamics at the scale of the studied area.

\subsection{Modelling}

The objective of the modelling in EXTREME is to assess the present and future risks of contamination of the marine environment linked to extreme events. The existing model (POC Partners, Toulouse University) is based on three coupled modules: a hydrodynamic model, a wave model and a sediment transport model (Estournel et al., 2003). A new module allowing the determination of pollutant (metals, radionuclides) concentration and translocation during extreme events is developed. Regarding future trends in pollutant translocation in the marine compartment, high resolution coastal simulation will be forced by the outputs of the regional ocean (OPA) and atmosphere (ARPEGE) climate models that provided a simulation over the 1960-2099 period under the A2 scenario of IPCC (Somot et al., 2006). We will focus on coastal processes responsible for re suspension and transport of contaminants.

\section{ILLUSTRATIVE RESULTS}

\subsection{Evidence for delayed source of long lived artificial radionuclides from a managed river banks (Rhône River, Southern France)}

The Rhône Valley was the centre of the French nuclear industry development from the $50 \mathrm{~s}$ and low level radioactive liquid effluents have been released over years mostly until 1990 when environmental 
protection directives led to radical decreases. The Rhône River is characterised by a major annual and inter-annual variability of the liquid flow due to the heterogeneity of the rainfall, which affect its large catchment area $\left(97800 \mathrm{~km}^{2}\right)$ and atypically large floods have reappeared over the last 15 years. Sedimentary storages of artificial radionuclides $\left({ }^{137} \mathrm{Cs},{ }^{241} \mathrm{Am},{ }^{238} \mathrm{Pu},{ }^{239+240} \mathrm{Pu}\right)$ within an alluvial embankment at the lower course of the River were observed and vertical accretion described based on a morphological approach combining chronological and sedimentary indicators. Our results show that deposits of the middle of the last century still contain activity levels one to two order of magnitude higher than suspended particles today transferred by the River (Figure 1). Some of these embankment types are currently moving back at a rapid space (approximately 3 metres a year since 1997) leading to reactivation of contaminated sedimentary storages.

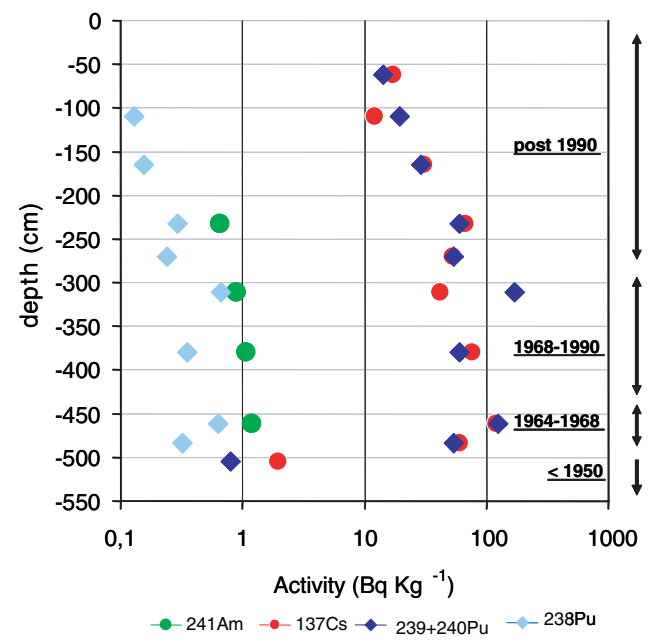

Figure 1. Long lived artificial radionuclides detected along a profile of an embankment at the lower course of the Rhône River (Fourques upstream Arles, left bank, from Eyrolle et al., 2008a).

\subsection{Consequences of the Rhône River floods on ${ }^{137} \mathrm{Cs}$, ${ }^{238} \mathrm{Pu}$ and ${ }^{239+240} \mathrm{Pu}$ fluxes towards the Mediterranean Sea}

The continental shelf of the Gulf of Lion (NW Mediterranean Sea) is one of the largest in the Mediterranean Sea and is characterised by large amounts of terrestrial material inputs and high rates of biological productivity. Sediment inputs to this environment are dominated by those from the Rhône River. The major role played by floods in annual sediment budgets is generally known and has been demonstrated in various case studies. For the North Western part of Mediterranean Sea, floods of the Rhône River are considered to be key moments for sedimentary fluxes. Important industrial and agricultural activities in the river basin result in strong nutrient and pollutant fluxes to the Rhône, an anthropogenic impact that also affects the marine system, since the Rhône inputs play a leading role in the functioning of the whole Gulf of Lion. Almost twenty nuclear reactors are located along the Rhône valley, representing Europe's biggest concentration of nuclear power plants. Until its closure in 1997, the Marcoule reprocessing plant of spent nuclear fuel released most of the liquid radioactive wastes to the river. Radioactive isotopes observed in the Rhône also originate from the weathering of the catchment basin contaminated by the global atmospheric fallout from the past nuclear tests carried out between 1945 and 1980 and the atmospheric fallout from the Chernobyl accident in 1986. These primary radioactive inputs are today several orders of magnitude lower than those observed at the beginning of the 90s. Nevertheless, floods strongly act on the reuptake of contaminated sediment accumulated 
Table 1. Mean annual fluxes of $137 \mathrm{Cs}$ and plutonium isotopes from the Rhône River towards the Mediterranean sea over the 2002-2004 period and contribution of flood events (from Eyrolle et al., 2008b).

\begin{tabular}{|l|c|c|c|}
\hline $\mathbf{2 0 0 2 - 2 0 0 4}$ & ${ }^{137} \mathrm{Cs}$ & ${ }^{238} \mathrm{Pu}$ & ${ }^{238+240} \mathrm{Pu}$ \\
\hline Mean annual flux & $140 \pm 40 \mathrm{GBq} \cdot \mathrm{y}^{-1}$ & $4,45 \pm 0,45 \mathrm{GBq} \cdot \mathrm{y}^{-1}$ & $2,3 \pm 0,7 \mathrm{GBq} \cdot \mathrm{y}^{-1}$ \\
\hline Flood contribution & $\mathbf{6 7 \%}$ & $\mathbf{5 5 \%}$ & $\mathbf{6 8 \%}$ \\
\hline
\end{tabular}

over the past 40 years of nuclear production/reprocessing. This particularly concerns long-lived particle reactive artificial radionuclides such as ${ }^{137} \mathrm{Cs},{ }^{238} \mathrm{Pu}$ and ${ }^{239+240} \mathrm{Pu}$. Our studies conducted from 2002 to 2004 show that more than $50 \%$ of caesium and plutonium annual fluxes are driven to the marine environment during floods that occurs only 10 to 20 days per year. $30 \%$ to $90 \%$ of these fluxes originate from the remobilisation of sedimentary storages (Table 1).

\section{Acknowledgments}

This study is supported by the Conseil Régional Midi Pyrénées, the Région Provence Alpes Côte d'Azur (inter regional CARMA project) and the French National Research Agency (ANR - EXTREMA project). Part of this work received labelling and additional supporting fundings from the competitiveness poles (Mer PACA and Gestion des Risques et Vulnérabilité des territories). The project is also supported by the ORME structure (Observatoire Régional Méditerranéen de l'Environnement - CEFREM). We sincerely thank technical support from enterprises In Vivo, Noveltis and Adhoc Vision, as vell as the CNR (Compagnie National du Rhône) for liquid flow rate data on the Rhône River.

\section{References}

Avila A., Alarcón M. and Queralt I., 1998, The chemical composition of dust transported in red rains - its contribution to the biogeochemical cycle of a holm oak forest in Catalonia (Spain), Atmospheric Environment, 32, 179-191.

Blandin J., Person R., Strout J.M., Briole P., Etiope G., Masson M., Golightly C.R., Lykousis V. and Ferentinos G.., 2002, ASSEM : Array of Sensors for long term SEabed Monitoring of geohazards Eurogoos conference, Athens, December 2002.

Caquineau S., Gaudichet A., Gomes L., Magonthier M.C. and Chatenet B., 1998, Saharan dust : Clay ratio as relevant tracer to assess the origin of soil-derived aerosols. Geophysical research letters, 25, 983-986, 1998.

CARMA, Conséquences des apports rhodaniens sur le milieu littoral associé : cas des évènements extrêmes, Programme Inter-Régionale Midi-Pyrénées \& Provence Alpes Côte d'Azur 2005-2006, Contrat 2005-19526/19527. 48 pp.

Charmasson S., Radakovitch O., Arnaud M., Bouisset P. and Pruchon A.-S., 1998, Long-core profiles of $137 \mathrm{Cs}, 134 \mathrm{Cs}, 60 \mathrm{Co}$ and $210 \mathrm{~Pb}$ in sediment near the Rhône River (Northwestern Mediterranea Sea). Estuaries, 21, 3, 367-378.

Charmasson S., 2003, 137Cs inventory in sediment near the Rhône mouth: role played by different sources, Oceanologica Acta 26, 435-441.

Dulac F., Moulin C, Planquette H., Schulz M. and Tartar M., 2004, African dust deposition and ocean colour in the eastern Mediterranean, Rapport Commission internationale CIESM, 37, 190, Congrès de juin 2004, Barcelone.

Durrieu de Madron X., Abassi A., Heussner S., Monaco A., Aloïsi J.C., Radakovitch O., Giresse P., Buscail R. and Kerhervé P., 2000, Particulate matter and organic carbon budgets for the Gulf of Lions (NW Mediterranean), Oceanologica Acta, 23, 6, 717-730.

Estournel C., Durrieu de Madron X., Marsaleix P., Auclair F., Julliand C. and R. Vehil, 2003, Observation and modelisation of the winter coastal oceanic circulation in the Gulf of Lions 
under wind conditions influenced by the continental orography (FETCH experiment). Journal of Geophysical Research, 108, C3, 7-1 to 7-18.

EXTREMA, Consequences of extreme meteo climatic events on sediments and associated contaminants within a coastal environment, ANR project, contract $\mathrm{N}^{\circ}$ ANR-06-VULN-005, 2007-2010.

Eyrolle F., Charmasson S. and Louvat D., 2004a, Plutonium isotopes in the lower reaches of the river Rhône over the period 1945-2000: Fluxes towards the Mediterranean Sea and sedimentary inventories, Journal of Environmental Radioactivity, Special issue, 74, 127-138.

Eyrolle F., Duffa C., Leprieur F., Rolland B., Antonelli C., Marquet J., Salaun G. and et Renaud Ph., 2004b, Conséquences radiologiques des inondations de décembre 2003 en Petite Camargue au lieu dit 'Claire Farine' - Résultats de l'expertise réalisée à la demande de la CLI du Gard, Rapport IRSN/DEI/SESURE/04-14.

Eyrolle F., Provansal M., Villiet J., Raccasi G., Radakovitch O., Gurriaran R. and Antonelli C., 2008 a, Evidence for delayed source of long lived artificial radionuclides from a managed river banks (Rhône River, Southern France), proceedings of the 11th International Symposium on the Interactions between Sediments and Water, Februart 17-22 2008, Esperance, Australia.

Eyrolle F., Rolland B. and Gurriaran R., 2008b, Consequences of the Rhône River floods on $137 \mathrm{Cs}, 238 \mathrm{Pu}$ and $239+240 \mathrm{Pu}$ fluxes towards the Mediterranean Sea, proceedings of the 11th International Symposium on the Interactions between Sediments and Water, Februart 17-22 2008, Esperance, Australia.

Ludwig W., Meybeck M. and Abousamra F., 2003, Riverine transport of water, sediments and pollutants to the Mediterranean Sea, UNEP MAP Technical report Series 141, UNEP/ MAP Athens 2003, $111 \mathrm{pp}$ (available at http://www.unepmap.org).

Maillet G., 2006, Apports de la géomorphologie à la détermination des facteurs de sensibilité radioécologique des berges - SENSIB volet Fluvial, Rapport de Post Doctorat IRSN/ DEI/SESURE/06.

Pham M. K., La Rosa J. J., Lee S. H., Oregioni B. and Povinec P. P., 2004, Deposition of Saharan dust in Monaco rain 2001-2002: Radionuclides and elemental composition, in press.

Rolland B., 2006, Transfert des Radionucléides artificiels par voie fluviale : Conséquences sur les stocks sédimentaires et les.

Somot S., Sevault F. and M. Déqué, 2006, Transient climate change scenario simulation of the Mediterranean Sea for the twenty-first century using a high-resolution ocean circulation model, Climate Dynamics, in press. 